\title{
Induction of domoic acid production in the toxic diatom Pseudo-nitzschia seriata by calanoid copepods
}

\author{
Anna Tammilehto ${ }^{\mathrm{a}, *}$, Torkel Gissel Nielsen ${ }^{\mathrm{b}, \mathrm{c}}$, Bernd Krock ${ }^{\mathrm{d}}$, \\ Eva Friis Møller ${ }^{\mathrm{e}}$, Nina Lundholm ${ }^{\mathrm{a}}$ \\ ${ }^{a}$ Natural History Museum of Denmark, University of Copenhagen, Sølvgade 83S, DK-1307 Copenhagen K, Denmark \\ ${ }^{\mathrm{b}}$ National Institute of Aquatic Resources, DTU Aqua, Section for Oceanecology and Climate, Technical University of Denmark, DTU, Kavalergården 6, \\ DK-2920 Charlottenlund, Denmark \\ c Greenland Climate Research Centre, Greenland Institute of Natural Resources, Nuuk, Greenland \\ ${ }^{\mathrm{d}}$ Alfred Wegener Institut-Helmholtz Zentrum für Polar- und Meeresforschung, Ökologische Chemie, Am Handelshafen 12, 27570 Bremerhaven, Germany \\ e Department of Bioscience, Roskilde, Aarhus University, Frederiksborgvej 399, PO Box 358, 4000 Roskilde, Denmark
}

\section{A R T I C L E I N F O}

\section{Article history:}

Received 16 August 2014

Received in revised form

26 November 2014

Accepted 28 November 2014

Available online 5 December 2014

\section{Keywords:}

Domoic acid

Pseudo-nitzschia seriata

Calanus

Diatom

Toxin production

Grazing

\begin{abstract}
A B S T R A C T
The toxic diatom Pseudo-nitzschia seriata was exposed directly and indirectly (separated by a membrane) to copepods, Calanus hyperboreus and $C$. finmarchicus, to evaluate the effects of the copepods on domoic acid production and chain formation in $P$. seriata. The toxicity of $P$. seriata increased in the presence of the copepods. This response was chemically mediated without physical contact between the organisms suggesting that it was induced by potential waterborne cues from the copepods or changes in water chemistry. Domoic acid production may be related to defense against grazing in $P$. seriata although it was not shown in the present study. To evaluate if the induction of domoic acid production was mediated by the chemical cues from damaged $P$. seriata cells, live $P$. seriata cells were exposed to a $P$. seriata cell homogenate, but no effect was observed. Chain formation in $P$. seriata was affected only when in direct contact with the copepods. This study suggests that the presence of zooplankton may be one of the factors affecting the toxicity of Pseudo-nitzschia blooms in the field.
\end{abstract}

(C) 2014 Elsevier B.V. All rights reserved.

\section{Introduction}

Many phytoplankton species produce toxic secondary metabolites, whose functions are still unknown in most groups of microalgae. The secondary metabolite domoic acid (DA) is a potent neurotoxin produced by several species in the diatom genus Pseudo-nitzschia Peragallo (reviewed in Lelong et al., 2012; Trainer et al., 2012). DA may accumulate in organisms grazing on toxic Pseudo-nitzschia species and afterwards be transferred to higher trophic levels (e.g. Scholin et al., 2000; McHuron et al., 2013) where it may lead to amnesic shellfish poisoning (ASP). The symptoms of ASP include e.g. nausea, diarrhea, short-term memory loss, paralysis and in extreme cases, death.

The first recorded ASP incident, which affected more than 100 humans took place in Prince Edward Island, Canada, in 1987, and

\footnotetext{
* Corresponding author. Tel.: +45 35330854 .

E-mail addresses: atammilehto@snm.ku.dk (A. Tammilehto), tgin@aqua.dtu.dk (T.G. Nielsen), Bernd.Krock@awi.de (B. Krock), efm@bios.au.dk (E.F. Møller), nlundholm@snm.ku.dk (N. Lundholm).
}

it was caused by consumption of DA-contaminated blue mussels (Bates et al., 1989). The effects of DA on sea birds, sea lions and fish have been studied (Fritz et al., 1992; Scholin et al., 2000; Lefebvre et al., 2012), whereas there is not much knowledge of possible effects of DA on, e.g. planktonic grazers such as copepods that feed on DA-producing Pseudo-nitzschia. Shaw et al. (1997) studied the effects of dissolved DA on the copepod Tigriopus californicus grazing on the non-toxic diatom Thalassiosira pseudonana. Reduced grazing due to DA was not observed, but DA was toxic to the copepods and caused mortality at relatively low concentrations (Shaw et al., 1997). In most grazing studies on toxic Pseudo-nitzschia the copepods have accumulated DA, but no apparent adverse effects on grazers, e.g. reduced grazing, were detected (Lincoln et al., 2001; Tester et al., 2001; Maneiro et al., 2005; Leandro et al., 2010). Hence, the potential role of DA as a grazing deterrent has not been supported. However, Bargu et al. (2003) found krill to feed discontinuously on toxic Pseudo-nitzschia multiseries, and the same observation was made by Tammilehto et al. (2012) when feeding copepods, Calanus finmarchicus and C. hyperboreus, with toxic $P$. seriata. Both studies suggested that the grazers suffered from physiological incapacitation. The indication that DA may affect 
grazing by copepods has implications for the phytoplankton, and may give toxic species an advantage over non-toxic ones (Huntley et al., 1986). To investigate whether DA deters copepod grazing on the toxic Pseudo-nitzschia species, and what the potential mode of action is, further studies are still needed.

The presence of grazers may affect phytoplankton morphology, such as the length of chains and colony size (Hessen and Van Donk, 1993; Jakobsen and Tang, 2002; Jiang et al., 2010; Selander et al., 2011; Bergkvist et al., 2012) and physiology (Jang et al., 2003). These responses may reduce the risk of being grazed, i.e. the defense mechanism is inducible. Selander et al. (2006) found that waterborne cues from the copepod Acartia tonsa induced paralytic shellfish poisoning toxin (PST) production in the dinoflagellate Alexandrium minutum, which led to reduced grazing of $A$. tonsa on A. minutum. It has also been shown that the chemical and morphological responses may take place simultaneously (Selander et al., 2012). Such inducible defenses may be beneficial in conditions where the risk of being grazed is unpredictable, as e.g. in marine environments, given that defensive traits are costly (Karban and Baldwin, 1997). In addition to the potential cues released by the grazers, mechanical damage of the algae may signal the risk of grazing, especially when feeding is "sloppy", even if the message may not always be reliable since algae also lyse, e.g. due to attack by viruses (Van Donk et al., 2011). The effect of mechanical damage on the potential inducible defenses in phytoplankton has been rarely studied (reviewed in Van Donk et al., 2011; see Lampert et al., 1994; Lürling, 1998). It is possible that the chemicals released by the grazers and the damaged cells interact to produce the potential signal that eventually induces the defense reaction in the phytoplankton (Van Donk et al., 2011). Indications that the presence of the copepods may enhance DA production in $P$. seriata were found by Tammilehto et al. (2012), where the DA cell quota in $P$. seriata increased after $12 \mathrm{~h}$ in the presence of $C$. hyperboreus. In the same study no increase in DA was found in the presence of $C$. glacialis or C. finmarchicus.

In the present study we explored the following questions:

1) Does the presence of the two copepod species Calanus hyperboreus and $C$. finmarchicus induce physiological or morphological responses, i.e. enhanced DA production or changes in chain formation in Pseudo-nitzschia seriata?

2) Are the potential cues involved in the induced response chemical or is physical contact required to elicit them?

3) Can the potential triggers be released from damaged $P$. seriata cells only, without the presence of the copepods?

\section{Materials and methods}

\subsection{Study organisms}

The copepods Calanus finmarchicus and $C$. hyperboreus were collected from Disko Bay $\left(69^{\circ} 14^{\prime} \mathrm{N}, 53^{\circ} 23^{\prime} \mathrm{W}\right)$ at a 300 -m-deep monitoring station (Madsen et al., 2001; Hansen et al., 2012) during the spring bloom in April 2012. Disko Bay is located on the western coast of Greenland. The copepods were sampled from the upper $100 \mathrm{~m}$ using a WP-2 net $(200 \mu \mathrm{m})$, transported to the laboratory in thermo boxes, picked individually using a stereo microscope in ice-chilled petri dishes and kept in the dark at the in situ temperature for a maximum of 1 week in $0.45-\mu \mathrm{m}$ filtered seawater and fed with Thalassiosira sp. prior to the experiments. Thereafter, the copepods were starved for $24 \mathrm{~h}$. The DA-producing $P$. seriata strain P5G3 was isolated as described in Tammilehto et al. (2012) and grown in 50\% silica-reduced L1-medium (Guillard and Hargraves, $1993)$ at 12:12 light:dark cycle. The length and width of $P$. seriata cells were $64.8 \pm 3.9$ (SD) $\mu \mathrm{m}$ and $5.5 \pm 0.8$ (SD) $\mu \mathrm{m}$, respectively.

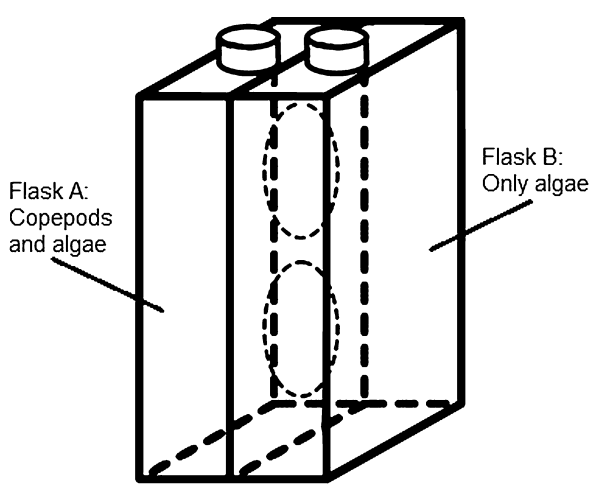

Fig. 1. Schematic diagram of the incubator with two flasks connected via two $2-\mu \mathrm{m}$ polycarbonate membranes (diameter $4.5 \mathrm{~cm}$ ). Flask A: Pseudo-nitzschia seriata plus copepods (except in the control); flask B: P. seriata only.

\subsection{Induction experiments with copepods}

The induction experiments were conducted in incubators consisting of two polystyrene tissue culture flasks (Sarstedt) (volume $\left.710 \mathrm{ml} \mathrm{flask}^{-1}\right)$ that were connected through two holes $(4.5 \mathrm{~cm}$ in diameter) covered by $2.0-\mu \mathrm{m}$ polycarbonate membranes to allow water exchange between flasks ( $\mathrm{A}$ and $\mathrm{B}$ ) but to prevent exchange of copepods and algal cells between the flasks (modified from Tang, 2003; Fig. 1). Non-toxic aquarium silicone (Dana Lim aquarium silicone 579) was used to glue the filters onto the polystyrene flasks and to connect the flasks. The permeability of the $2-\mu \mathrm{m}$ polycarbonate membrane was tested visually by observing the transport of food dye from one flask to the other. Tang (2003) used similar membranes and reported reaching the diffusion equilibrium of $\sim 50 \%$ and $90 \%$ after 3 and 5 days, respectively. The incubators (flasks A and B) both contained $P$. seriata culture. The copepods and $P$. seriata cells were added to flask A separated by the $2.0-\mu \mathrm{m}$ polycarbonate membrane from the $P$. seriata cells in flask B (Fig. 1; Table 1).

The sea water used for the experiments was collected at least 1 week before starting the experiments to minimize the potential cues originating from the field. The salinity 35 water was filtered $\left(0.45-\mu \mathrm{m}\right.$ pore size) and stored at $4 \pm 2{ }^{\circ} \mathrm{C}$. Both flasks (A and B) of the incubators were inoculated with $P$. seriata at a concentration of 1000 cells $\mathrm{ml}^{-1}$, corresponding to an average of $162 \mu \mathrm{g} \mathrm{Cl}^{-1}$ (for calculations see Tammilehto et al., 2012). This cell concentration was achieved by pooling together four $P$. seriata batch cultures (for growth conditions see Section 2.1, the batch cultures had been grown for 9 days) in early stationary phase $\left(16,000\right.$ cells $\mathrm{ml}^{-1}$ in $1.1 \mathrm{l}$ ) and diluting it with $16.9 \mathrm{l}$ of $0.45-\mu \mathrm{m}$ filtered seawater (=a pooled culture) on the day when the experiment was started. To measure the DA concentration of $P$. seriata before the experiments, triplicate subsamples $(100 \mathrm{ml})$ of $P$. seriata were taken from the

Table 1

Experimental setup of the incubation experiments with copepods and homogenized Pseudo-nitzschia seriata cells, showing the contents of flask A, containing copepods or homogenized $P$. seriata (except in the control) plus live algae, and $\mathrm{B}$, containing only live algae.

\begin{tabular}{llll}
\hline Experiment & Treatment & Flask & \\
\cline { 3 - 4 } & & A & B \\
\hline Copepods & $\begin{array}{l}\text { Control } \\
\text { C. hyperboreus }\end{array}$ & $\begin{array}{l}\text { Algae } \\
\text { Copepods and } \\
\text { algae } \\
\text { C. finmarchicus }\end{array}$ & $\begin{array}{l}\text { Algae } \\
\text { Algae }\end{array}$ \\
algae & Algae \\
Damaged cells & $\begin{array}{l}\text { Control } \\
\text { Cell homogenate } \\
\text { addition }\end{array}$ & $\begin{array}{l}\text { Algae } \\
\text { Homogenized } \\
\text { algae and algae }\end{array}$ & $\begin{array}{l}\text { Algae } \\
\text { Algae }\end{array}$ \\
\hline
\end{tabular}


pooled culture using a 100-ml syringe and filtered onto GF/F filters using gentle vacuum. The samples were stored at $-20^{\circ} \mathrm{C}$ until analysis. A few hours before the experiments, actively swimming copepods were added to the flasks filled with $0.45-\mu \mathrm{m}$ filtered seawater and kept at $4{ }^{\circ} \mathrm{C}$.

The experiments were started by adding $C$. hyperboreus or $C$. finmarchicus to flask A, two or eight copepods, respectively, per flask. The control incubator (flask A) contained no copepods. For cell counts, a 3-ml sample was taken from each flask and fixed with $1 \%$ (final concentration) acidic Lugol's solution. The grazing treatments and the controls were run simultaneously in quadruplicate and in triplicate, respectively. The incubators were mounted on a plankton wheel rotating at $1.3 \mathrm{rpm}$. The experiment was run for 8 days at $4 \pm 2{ }^{\circ} \mathrm{C}$ using a $12: 12$ light:dark cycle under a light intensity of $100 \mu \mathrm{mol}$ photons $\mathrm{m}^{-2} \mathrm{~s}^{-1}$.

Cell and DA concentrations were quantified again on days 2 , 5 and 8. Both flasks (A and B) were sampled simultaneously, and the flasks were refilled filtered seawater. On day 2 , the cell concentration samples were fixed with $10 \%$ glutaraldehyde (final concentration) to preserve the chains. Acidic Lugol's solution ( $1 \%$ final concentration) was used for fixation on the other days and the samples were counted within three months after the experiments. On day 3, $19 \mathrm{ml}$ of $P$. seriata batch culture (350,000 cells, culture grown for 12 days) was added directly to the flasks with copepods (flask A) to ensure that the copepods had enough P. seriata cells for grazing. The same volume of $P$. seriata was added to the control flask A to ensure similar treatment of the grazing and the control flasks. The dilutions due to sampling and adding cells on day 3 were considered in calculating the growth and ingestion rates. The growth rate was calculated according to Frost (1972) and the ingestion rate according to Harris et al. (2005) (for formulas see Tammilehto et al., 2012).

At the end of the experiment (day 8), samples were taken for cell counts $(4 \mathrm{ml}), \mathrm{DA}(200 \mathrm{ml})$ and chlorophyll-a concentration of $P$. seriata cells. In addition to measuring the particulate DA concentration of the cells collected on GF/F filters, a 3-ml sample of the filtrate was taken to measure the concentration of dissolved DA. The filtrate samples were stored at $-20^{\circ} \mathrm{C}$ prior to analysis. The DA cell quota was calculated by dividing the amount of DA collected on the GF/F filter ( $P$. seriata cells) by the cell number. In addition, the ratio between dissolved DA and cell numbers was calculated. To measure chlorophyll-a concentration, a 100-ml sample from each flask was filtered onto GF/F filters using gentle vacuum. The filters were then extracted in $5 \mathrm{ml}$ of $96 \%$ ethanol for $24 \mathrm{~h}$ (Jespersen and Christoffersen, 1987) and measured fluorometrically before and after $\mathrm{HCl}$ addition, using a Turner fluorometer (TD-700) calibrated against a chlorophyll-a standard. The number of copepods per flask was recorded at the end of the experiment and their condition checked visually.

\subsection{Induction experiment with damaged P. seriata cells}

Flask A contained live and homogenized $P$. seriata cells and flask B only live $P$. seriata cells (Table 1 ). The $P$. seriata homogenate was prepared by filtering a known volume of culture onto a $2.0-\mu \mathrm{m}$ polycarbonate filter using gentle vacuum, after which the cells on the filter were homogenized using an autoclaved mortar. In the controls, both flasks contained only live $P$. seriata cells. All the incubators were filled with aged $0.2-\mu \mathrm{m}$ filtered seawater with a salinity of 30 and $P$. seriata culture $\left(15 \mathrm{ml}\right.$ of 50,000 cells $\mathrm{ml}^{-1}$ ) was added to each flask to reach a final concentration of 1000 cells $\mathrm{ml}^{-1}$. The homogenate of $P$. seriata culture, corresponding to the concentration of 1000 cells $\mathrm{ml}^{-1}$ in $710 \mathrm{ml}$ was added into flask A. The filter was rinsed with a known volume of $0.2-\mu \mathrm{m}$ filtered seawater to collect the homogenate. To ensure that the cells were crushed, the homogenate was checked visually using an inverted microscope (Olympus CKX31) at 200× magnification before use. The homogenate was added to flask A directly after homogenization and care was taken to keep the homogenate cool at all times. After filling the incubators with $0.2-\mu \mathrm{m}$ filtered seawater and the $P$. seriata culture, $1.65 \mathrm{ml}$ of the homogenate was added to the treatment flask $A$ and the same volume of $0.2-\mu \mathrm{m}$ filtered sea water into the control flask A. Both the homogenate and control treatments were run in quadruplicate. The incubation experiment was run on a plankton wheel $(1.1 \mathrm{rpm})$ for 8 days at $3 \pm 1^{\circ} \mathrm{C}$ using 12:12 light:dark cycle under a light intensity of $100 \mu \mathrm{mol}$ photons $\mathrm{m}^{-2} \mathrm{~s}^{-1}$.

Samples for cell and DA concentrations were collected and treated as described in Section 2.2. The homogenate of damaged $P$. seriata cells was prepared and added to the treatment flasks daily during the experiment (days $0-7$ ) to provide fresh potential cues, and at the same time an equal volume of $0.2-\mu \mathrm{m}$ filtered sea water was added to the control flasks. The $P$. seriata cultures used for inoculating the experimental incubators and for making cell homogenate were grown at $4{ }^{\circ} \mathrm{C}$ using $12: 12$ light:dark cycle under a light intensity of $100 \mu \mathrm{mol}$ photons $\mathrm{m}^{-2} \mathrm{~s}^{-1}$ and were harvested at late exponential to late stationary phase (cultures grown for 16-23 days).

Subsamples $(50 \mathrm{ml})$ for measuring dissolved inorganic nitrogen (ammonium, nitrate and nitrite), dissolved inorganic phosphorus (phosphate) and dissolved silica at the beginning of the experiment were taken from two extra flasks similar to the control flasks and the same flasks were used for measuring $\mathrm{pH}$. At the end of the experiment (day 8) $\mathrm{pH}$ was measured from all the B flasks. $\mathrm{pH}$ was measured using analytical pH-meter (Radiometer). The nutrient samples at the end of the experiment (day 8) were collected from one control flask B and one treatment flask B. The sample for dissolved silica analysis was passed through a $5.0-\mu \mathrm{m}$ polycarbonate filter and those for nitrogen and phosphorus analyses through $\mathrm{GF} / \mathrm{C}$ filters. The nutrient filtrates were frozen at $-20^{\circ} \mathrm{C}$ immediately after sampling and later analyzed at the Aarhus University (Denmark) on a flow injection autoanalyzer, following Hansen and Koroleff (1999). DA analyses for the incubation experiments were conducted as described in Tammilehto et al. (2012). The detection limit for DA was $10 \mathrm{ng}$ sample $^{-1}$.

\subsection{Microscopy}

Pseudo-nitzschia cell concentrations and chain length (number of cells in per chain) were enumerated in a Sedgewick-Rafter chamber using an inverted microscope (Nikon TMS and Olympus CKX31) at $100 \times$ magnification. A minimum of 400 cells was counted in each sample and if a sample contained fewer than this, at least half of the cells in the counting chamber were counted. The length and width of the cells were measured using Olympus BX53 microscope at $400 \times$ magnification.

\subsection{Statistical analyses}

Changes over time within each treatment were tested using repeated measures ANOVA(RM ANOVA), and the Friedman test was used as a non-parametric alternative. Paired samples were tested using the paired $t$-test or the non-parametric Mann-Whitney $U$ test. The differences between means were tested using the $t$-test (two samples) and one-way ANOVA (three or more samples) or the non-parametric Mann-Whitney $U$-test and the Kruskall-Wallis test. Normal distribution was tested using the Shapiro-Wilk test and homogeneity of variances using Levene's test. If the dataset violated the assumption of normal distribution or homogeneity of variances, it was ln transformed. If the assumptions of normality or variance homogeneity were not fulfilled, even after the transformation, a non-parametric test was used. The $X^{2}$-test was used 
to compare the proportions of cells in single cells and chains (three categories: single cells, 2-cell chains and 3- or more cell chains) using the proportions in the control as the expected frequency. A common significance level of 0.05 was applied.

\section{Results}

The DA cell quota (toxicity) of $P$. seriata increased during the experiment with both $C$. hyperboreus and $C$. finmarchicus, in contrast to the control where the DA cell quota of $P$. seriata remained stable (Fig. 2). The toxicity of $P$. seriata increased in both sides of the incubators, i.e. both when cells were in direct physical contact with the copepods (flask A) and also when the copepods and the algae were physically separated into different compartments and only water exchange between the compartments was allowed through a $2-\mu \mathrm{m}$ polycarbonate membrane (flask $\mathrm{B}$ ). On day 0 , the DA cell quota of $P$. seriata was below the limit of detection. The greatest toxicity increase was recorded when $P$. seriata was in direct physical contact with $C$. hyperboreus, rising from undetected to $13.1 \mathrm{pg}$ DA cell $^{-1}$ (day 8 mean) in flask A (Fig. 2A). The toxicity of $P$. seriata in flask A with $C$. hyperboreus increased significantly during the experiment (RM ANOVA, $F_{2,6}=58.4, p<0.01$ ), and post-hoc analysis with Bonferroni adjustment showed the toxicity of $P$. seriata to be significantly higher on days 5 and 8 than on day $2(p<0.05$ and $p<0.01$, respectively) (Fig. 2A). In flask B with cues from $C$. hyperboreus, a
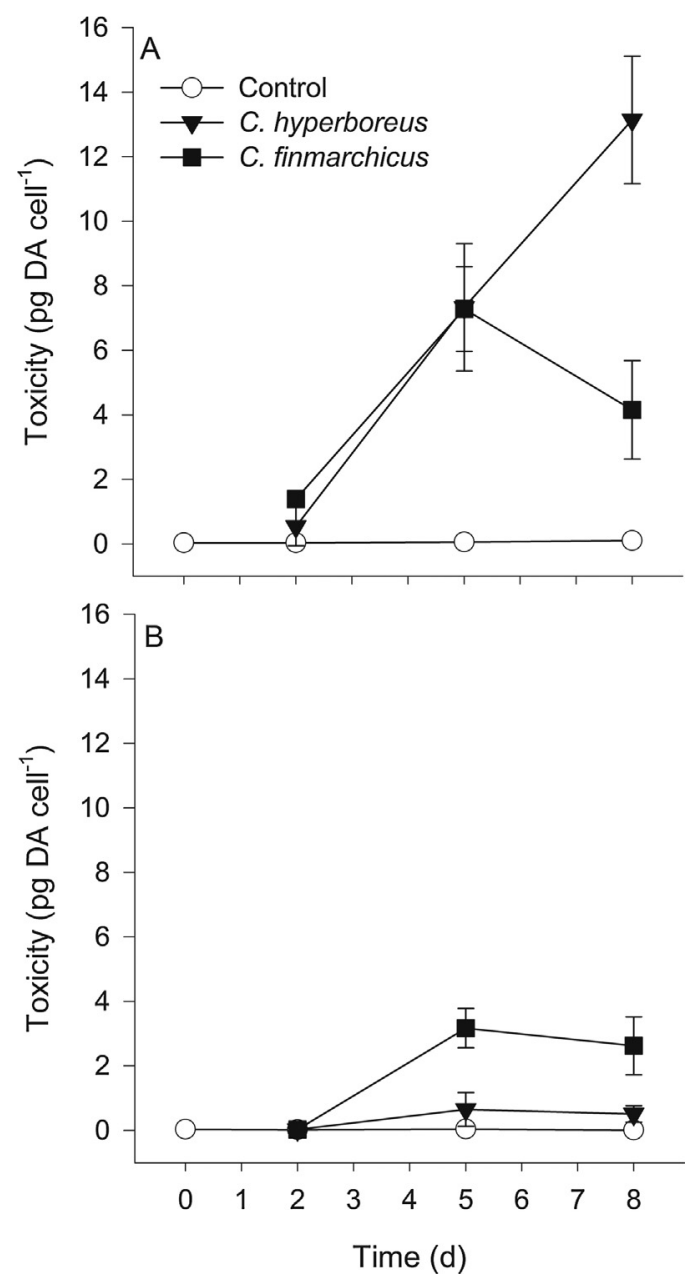

Fig. 2. Domoic acid (DA) cell quota (pg DA cell ${ }^{-1}$, mean \pm SD) of Pseudo-nitzschia seriata in different treatments on days $0,2,5$ and 8 . (A) Flask A with copepods (except control); (B) flask B containing only algae with cues from the copepods (except control). On day 0 , DA cell quota measured from the pooled culture. In the control, $n=3$ and in the copepod treatments, $n=4$.
Table 2

Domoic acid (DA) cell quota of Pseudo-nitzschia seriata (pg DA cell ${ }^{-1}$ ) and dissolved $\mathrm{DA}$ concentration in the culture filtrate $\left(\mathrm{ng} \mathrm{DA} \mathrm{ml} \mathrm{l}^{-1}\right)$ on day $8($ mean $\pm \mathrm{SD})$ in flask $\mathrm{A}$, containing copepods (except control) and flask B, with cues from copepods (except control).

\begin{tabular}{|c|c|c|c|}
\hline & & Cellular (pg DA cell ${ }^{-1}$ ) & Filtrate $^{\mathrm{a}}\left(\mathrm{ng} \mathrm{DA} \mathrm{m} \mathrm{m}^{-1}\right)$ \\
\hline \multirow[t]{3}{*}{ A } & Control & $0.10 \pm 0.04$ & bd \\
\hline & C. hyperboreus & $13.1 \pm 1.98$ & $17.0 \pm 5.55$ \\
\hline & C. finmarchicus & $4.15 \pm 1.52$ & bd \\
\hline \multirow[t]{3}{*}{ B } & Control $^{\mathrm{b}}$ & $0.01 \pm 0.00$ & bd \\
\hline & C. hyperboreus & $0.51 \pm 0.25$ & bd \\
\hline & C. finmarchicus & $2.62 \pm 0.89$ & bd \\
\hline
\end{tabular}

\footnotetext{
a $\mathrm{bd}=$ measurement below the limit of detection.

b One measurement of cellular DA below the limit of detection.
}

significant increase in toxicity (RM ANOVA, $F_{2,6}=5.6, p<0.05$ ) was also seen, but post-hoc analysis with Bonferroni adjustment could not reveal significant pairwise differences (Fig. 2B). The toxicity of $P$. seriata also changed significantly when in physical contact with C. finmarchicus (RM ANOVA, $F_{2,6}=30.3, p<0.01$ ), reaching the highest level on day 5 ( 7.3 pg DA cell ${ }^{-1}$, mean) (Fig. 2A). The post-hoc analysis with Bonferroni adjustment showed that the toxicity was significantly higher on day 5 than on day $2(p<0.05)$. In flask B with cues from $C$. finmarchicus, the toxicity of $P$. seriata changed significantly (RM ANOVA, $F_{2,6}=36.3, p<0.001$ ) and was higher than in flask B with cues from $C$. hyperboreus, but lower than in flask A with $C$. finmarchicus (Fig. 2). The post-hoc analysis with Bonferroni adjustment revealed that the toxicity of $P$. seriata in flask B with cues from $C$. finmarchicus was significantly higher on days 5 and 8 than on day 2 ( $p<0.01$ and $p<0.05$, respectively). In the controls, the toxicity of $P$. seriata did not change in flask A (Friedman's test, $X_{3}^{2}=4.2, p=0.24$ ) nor in flask B (Friedman's test, $X_{3}^{2}=3.4, p=0.33$ ) during the experiment (Fig. 2).

The DA cell quota and the concentration of dissolved DA in the medium on day 8 were compared between treatments (Table 2). Cellular DA was detected in all the treatments, although substantially less in the controls compared to the grazing treatments, especially in flask A (Table 2). Dissolved DA was observed only with C. hyperboreus in flask A, whereas in the other flask, the measurements were below the detection limit (bd) (Table 2). The DA cell quota was significantly higher in the flasks with the copepods than in the control and also higher with $C$. hyperboreus in comparison to $C$. finmarchicus (one-way ANOVA, $F_{2,8}=68.6, p<0.001$, posthoc analyses with Bonferroni adjustment: control-C. hyperboreus: $p<0.001$, control-C. finmarchicus: $p=0.025, C$. hyperboreus-C. finmarchicus: $p<0.001$ ) (Fig. 2; Table 2). In flask B on day 8, the DA cell quota (In transformed) was significantly higher with cues from C. finmarchicus compared to the control and with cues from $C$. hyperboreus; $C$. hyperboreus was also significantly higher than the control (one-way ANOVA, $F_{2,8}=171.2, p<0.001$, post-hoc analyses with Bonferroni adjustment: control-C. finmarchicus: $p<0.001$, $C$. hyperboreus-C. finmarchicus: $p=0.001$, control-C. hyperboreus: $p<0.001$ ) (Fig. 2; Table 2). The concentration of dissolved DA (external DA in the medium) on day 8 was significantly higher in flask $A$ with C. hyperboreus than in the control flask A (bd) (Kruskall-Wallis test, $X_{2}^{2}=8.9, p=0.012$, post-hoc pairwise comparison, $p=0.009$ ), showing that the $P$. seriata cells also excreted or leaked the toxin (Table 2). The concentration of dissolved DA with $C$. finmarchicus was nondetectable in flask A, however, and it did not differ significantly from $C$. hyperboreus or the control (non-censored values were used). In flask B, the concentrations of dissolved DA with cues from $C$. hyperboreus and $C$. finmarchicus and in the control were all below the limit of detection (Table 2). The amount of dissolved DA per $P$. seriata cell in flask A with C. hyperboreus was $21.3 \pm 19.9 \mathrm{pg}$ DA cell ${ }^{-1}$. 


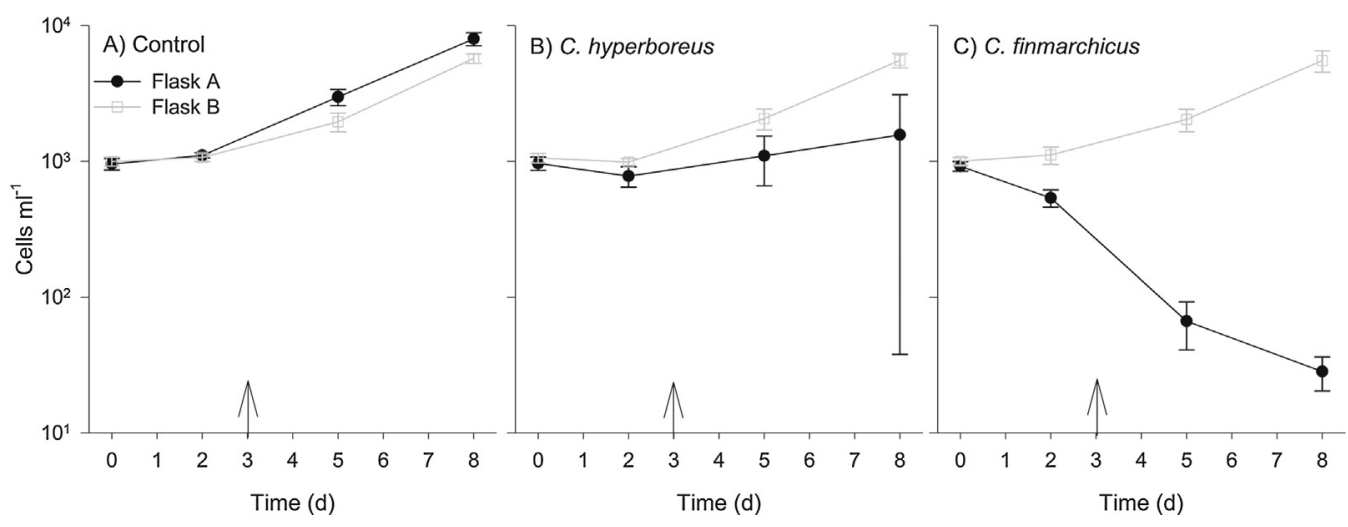

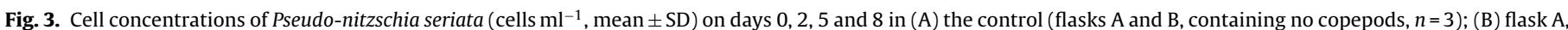


when extra culture was added to the flask A on day 3.

$P$. seriata grew in all experimental incubators (Fig. 3) and at the start of the experiment cell densities were the same in flask A (Kruskall-Wallis test, $X_{3}^{2}=0.33, p=0.85$ ) for each treatment. The algae reached the highest cell density in the control flask $A$, where there were no grazers and extra culture was added on day 3. In flask A, where the algae were in direct contact with the copepods, the cell densities decreased due to grazing (Fig. 3). The decrease was significant (one-way ANOVA, $F_{2,8}=55.0, p<0.001$ ) and more pronounced with $C$. finmarchicus than with $C$. hyperboreus. The post-hoc analyses with Bonferroni adjustment revealed that the cell concentrations were significantly lower in flask A with C. hyperboreus and C. finmarchicus than in the control flask A (both $p$-values $<0.001)$ at the end of the experiment, confirming that the copepods were grazing on $P$. seriata. In flask $B$, there were no differences in cell concentrations between treatments at the start (one-way ANOVA, $F_{2,8}=0.75, p=0.50$ ) nor at the end of the experiment (one-way ANOVA, $F_{2,8}=0.08, p=0.93$ ). The overall net growth rate (between days 0 and 8 ) was similar in all $B$ flasks (oneway ANOVA, $F_{2,8}=0.38, p=0.70$ ), indicating homogeneous growth conditions (data not shown).

Both $C$. hyperboreus and $C$. finmarchicus grazed on $P$. seriata during the 8-day incubation (Figs. 3 and 4) and no copepod mortality was detected. The mean ingestion rates during the

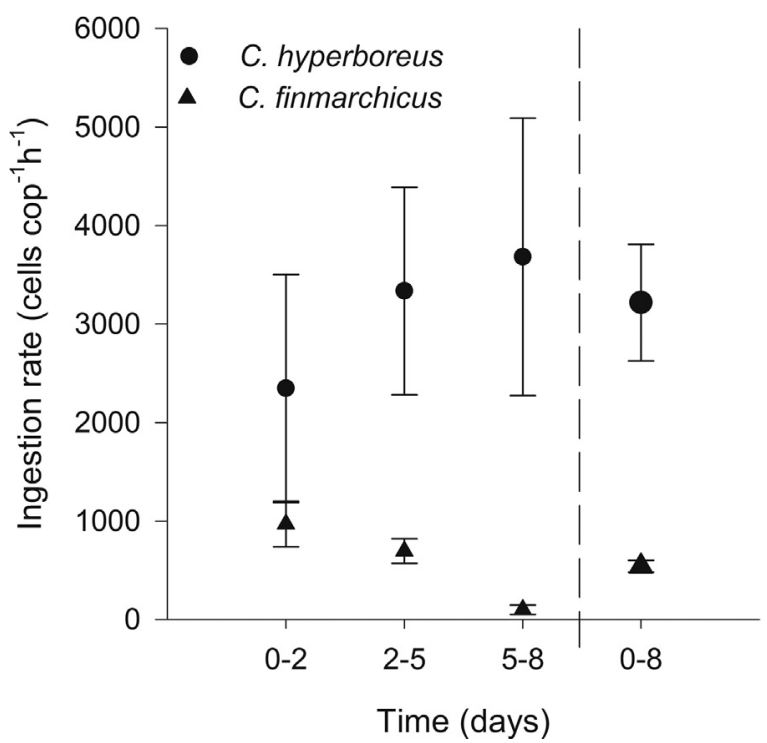

Fig. 4. Ingestion rates (cells copepod ${ }^{-1} \mathrm{~h}^{-1}$, mean $\pm \mathrm{SD}, n=4$ ) of Calanus hyperboreus and $C$. finmarchicus on days $0-2,2-5,5-8$, and $0-8$. experiment for C. hyperboreus and C. finmarchicus were 3219 and 542 cells copepod ${ }^{-1} \mathrm{~h}^{-1}$, respectively (Fig. 4), and C. hyperboreus ingested significantly more cells than did $C$. finmarchicus ( $t$-test; variances not equal; $t_{3.06}=9.0, p=0.003$ ). The mean ingestion rate of $C$. hyperboreus was highest from days 5 to 8 but there were no significant differences in ingestion rates of $C$. hyperboreus between the different time points (RM ANOVA, $F_{2,6}=1.0, p=0.42$ ). $C$. finmarchicus ingested $P$. seriata at significantly different rates during the experiment (RM ANOVA, $F_{2,6}=27.6, p=0.001$ ) and post-hoc analysis with Bonferroni correction showed that the ingestion rate was significantly lower on days 5 to 8 than on days 0 to 2 and 2 to 5 ( $p=0.017$ and $p=0.005$, respectively) (Fig. 4).

Adding homogenate of $P$. seriata to the $P$. seriata culture did not affect the toxicity of the culture during the experiment (Fig. 5). There were significant differences in toxicity between days in flask A with homogenate (RM ANOVA, $F_{2,6}=8.1, p=0.020$ ) and post-hoc pairwise comparisons without adjustment showed toxicity to be significantly higher on day 2 than on day $8(p=0.043)$ (with Bonferroni adjustment no differences could be detected). However, the same significant difference between days was also detected in the control flask A (Friedman test, $X_{2}^{2}=8.0, p=0.018$, post-hoc pairwise comparisons $p=0.014)$. Hence, the minor change in toxicity on day 2 in flasks A was due to factors other than adding the homogenate and there was no significant difference in toxicity between the treatments in flask A on day 2 ( $t$-test, $t_{6}=-0.51, p=0.63$ ). In $\mathrm{B}$ flasks (control and treatment), toxicity did not change significantly during the experiment (Friedman test, $X_{2}^{2}=1.5, p=0.47$, and RM ANOVA, $F_{1.02,3.06}=0.042, p=0.86$, respectively). Because the assumption of sphericity was not met (assessed by Mauchly's test), the Greenhouse-Geiser correction was applied for the RM ANOVA on the treatment flask B. Cell numbers decreased in all the flasks to around $\sim 500$ cells $\mathrm{ml}^{-1}$ until day 5 , after which they remained stable or increased slightly until day 8 (data not shown). Net growth rates did not differ between the control and the treatment in flask A ( $t$-test, $t_{6}=-2.3, p=0.057$ ) nor in flask B (Mann-Whitney, $U=4.0$, $z=-1.2, p=0.34$ ), confirming uniform growth conditions (data not shown). Dissolved inorganic nitrogen and silica levels decreased both in the control and treatment incubators (flask B) during the experiment and were at the same level (data not shown). There was little phosphate in the seawater used (mean $1.3 \mu \mathrm{moll}^{-1}$ ) and its level did not change in the control but decreased slightly in the treatment incubator (flask B) (data not shown). $\mathrm{pH}$ values were 7.9 in both the control and treatment B flasks at the end of the experiment ( $t$-test, $t_{6}=-1.1, p=0.33$ ).

Changes in the chain length of $P$. seriata were observed in the experiment with copepods but not in the experiment with the $P$. seriata homogenate. The proportion of single cells versus cells in 

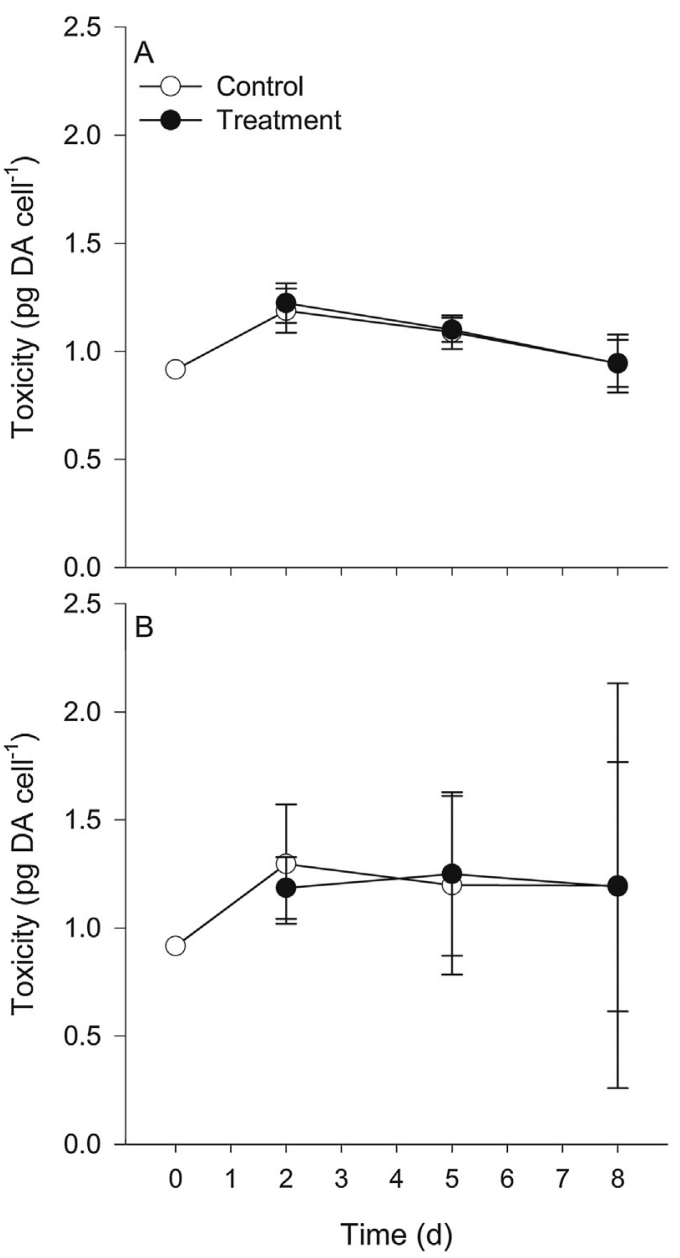

Fig. 5. Domoic acid (DA) cell quota (pg DA cell ${ }^{-1}$, mean \pm SD) of Pseudo-nitzschia seriata in the control $(n=4)$ and the homogenate treatment $(n=4)$ on days $0,2,5$ and 8 in (A) flask A, with homogenate added (except control), and (B) flask B, containing only algae.

chains during the experiment was more or less stable when $C$. hyperboreus and $C$. finmarchicus grazed on $P$. seriata, but only in the flasks where the copepods were in physical contact with the cells (flask A), whereas in the controls, the proportion of cells in chains increased during the experiment (Fig. 6). In the experiment with the $P$. seriata homogenate, the proportion of single cells was $\sim 60 \%$ throughout the experiment in both the control and treatment flasks (data not shown). The $X^{2}$-test did not reveal relevant differences between the control and the grazing treatment/homogenate addition because significant differences between the control and the treatments already existed at the start of the experiment.

\section{Discussion}

We show that the toxicity of $P$. seriata cells increased significantly in the presence of copepods. The response is chemically mediated, i.e. it was also found when the organisms had no physical contact. Chemical cues from the damaged $P$. seriata cells alone did not enhance DA production in live $P$. seriata cells.

The significant increase in toxicity of $P$. seriata in the presence of copepods, but without physical contact, suggests that waterborne cues or changes in water chemistry induced the cellular response. The toxicity of $P$. seriata increased more in the presence of cues from C. finmarchicus than with $C$. hyperboreus, when the copepods were not in physical contact with the diatom cells. However, the toxicity of $P$. seriata peaked when the cells were in direct contact with both
Calanus species and the highest DA cell quota was recorded after 8 days with $C$. hyperboreus. We cannot totally rule out the possibility that the toxicity of $P$. seriata in direct contact with the copepods increased because of selective grazing of the copepods on less toxic $P$. seriata cells. However, we find it unlikely because $C$. finmarchicus is not known to discriminate between toxic and non-toxic Pseudonitzschia species (Leandro et al., 2010). Moreover, there was a large difference in toxicity between the $P$. seriata cells in direct contact with the copepods and the control. Instead, we would expect to see a more pronounced chemically mediated response when the copepods and the algae are in physical contact, since the response is likely to be attenuated when the signal must first pass through the $2.0-\mu \mathrm{m}$ polycarbonate membrane. An explanation for this could be that the cues have lipophilic components, which partially adsorb to the polycarbonate membrane and do not entirely pass through it. A similar attenuation in response was observed in an analogous study on the PST-producing dinoflagellate A. minutum in the presence of three calanoid copepods (Bergkvist et al., 2008).

Triggers for DA production in Pseudo-nitzschia species have been attributed to environmental factors, e.g. nutrients in relation to the growth phase (reviewed in Bates, 1998; Lelong et al., 2012), pH (e.g. Lundholm et al., 2004), and trace metal limitation or toxicity (Maldonado et al., 2002). Evidence of allelopathic effects of DA, however, has not been found (Lundholm et al., 2005). DA is an amino acid and thus nitrogen is needed for its synthesis. Since diluted L1-medium (1/16) with reduced silicate was used in the present study, with an extra addition of medium containing $P$. seriata on day 3, we assume that no other nutrient except silicate (which was intentional) was limiting the growth of the algae in any experimental flask. This is supported by the equal growth rates observed in flask B of the control and treatments. In flask A where the copepods could graze on the algae, the growth of $P$. seriata was assumed to be similar to the other experimental flasks, so that the observed difference in cell concentration was due only to grazing. The copepods excrete or leak nutrients, such as ammonium, which may alter the growth conditions of the algae in the experimental flasks containing the copepods with respect to available nutrients and their ratios. High levels of ammonium $(>200 \mu \mathrm{M})$ may lead to increased cellular DA quotas in Pseudo-nitzschia but, at the same time, may also result in lowered growth rates (Bates et al., 1993). No change in growth was observed, even when the $P$. seriata cells were not in direct contact with the copepods in B flasks, where the DA cell quota increased significantly. Therefore, we assume that factors other than nutrients caused the increase in DA production. Levels of major inorganic nutrients have been measured in only a few studies, which have shown that chemicals released by the zooplankton induced either physiological or morphological responses in phytoplankton (Selander et al., 2006; Long et al., 2007; Lundgren and Granéli, 2010); however, the nutrients themselves have not been found to be the inductive factor in these studies. Selander et al. (2006) assumed that the possible effect of excretions (ammonium) from $A$. tonsa to be negligible at saturating nutrient conditions in comparison to the effect of chemical cues from A. tonsa in enhancing PST production A. minutum. This was later supported by the observation that ammonium concentrations did not differ between the grazing treatments and the controls, although the cell-specific PST content of $A$. minutum increased significantly in the presence of $A$. tonsa in nitrate-rich but not in low-nitrate conditions (Selander et al., 2008). Colony formation in the green algae Scenedesmus also seems to be induced by special grazer-released infochemicals rather than by excretory products of the grazers, or other nutrients (Lürling, 2001).pH is known to affect DA production in Pseudo-nitzschia species but the results from studies are contradictory. Lundholm et al. (2004) and Trimborn et al. (2008) found that elevated pH increased DA cell quota in P. multiseries, whereas Sun et al. (2011) showed that the 


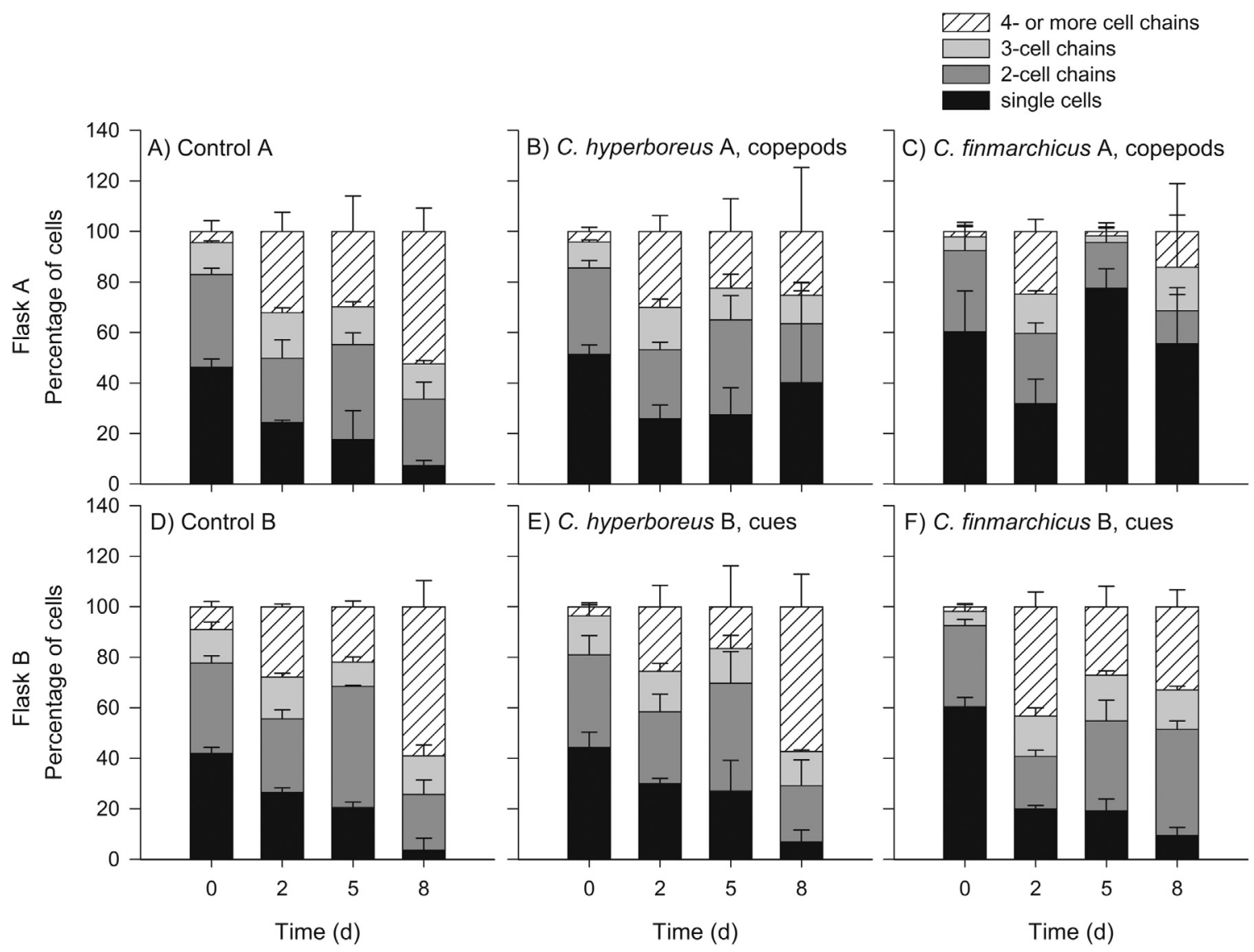

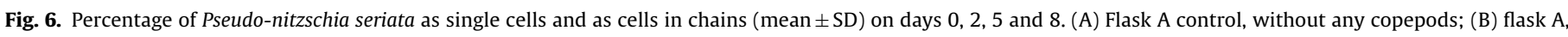

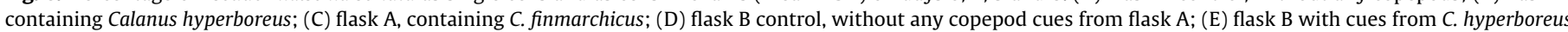
in flask A; (F) flask B with cues from $C$. finmarchicus in flask A. All flasks contained algae. In the control, $n=3$ and in the copepod treatments, $n=4$.

DA levels of $P$. multiseries increased with lowered $\mathrm{pH}$. In the present study, $\mathrm{pH}$ is expected to increase as $\mathrm{CO}_{2}$ is used for photosynthesis, but it is likely to be counterbalanced by the respiration of the copepods that produce $\mathrm{CO}_{2}$. Because $\mathrm{pH}$ was not measured in the present study in the flasks that contained the copepods and because of the obviously complex mechanisms by which it may affect DA production, we cannot totally exclude the possibility that $\mathrm{pH}$, at least in part, had an impact on the DA levels. Long et al. (2007) and Lundgren and Granéli (2010) found no differences in $\mathrm{pH}$ between the grazing treatments ( $A$. tonsa and $P$. globosa) and controls (only $P$. globosa). In other similar induction experiments with copepodites and $P$. seriata, no significant changes in $\mathrm{pH}$ were found (N. Lundholm unpubl.). In the experiment with homogenate added, no differences in $\mathrm{pH}$ were observed between the control and treatment.

In the present study, DA was produced during the exponential growth phase. The DA cell quota of $P$. seriata increased at the same time that cell numbers increased until day 5 with cues from $C$. finmarchicus in flask B. As well on day $8, P$. seriata was more toxic in flask B with cues from $C$. hyperboreus than in the control. With physical contact between the copepods and the algae (flask A), the DA cell quota of $P$. seriata increased until day 5 with $C$. finmarchicus, and until the end of the experiment (day 8 ) with $C$. hyperboreus. This indicates that actively dividing cells were producing increasing amounts of DA. This is contrary to the findings of most earlier studies which showed that the highest DA levels occured during the stationary growth phase, when cell division ceased (reviewed in Bates, 1998; Fehling et al., 2004; Thessen et al., 2009). Garrison et al. (1992) reported that $P$. australis produced DA during the exponential phase, but concluded that the results could be biased due to the very dense starting inoculum, which might have stressed the algae and, hence, enhanced DA production. $P$. australis grown on urea produced DA when growing exponentially, but the exponential growth rate of $P$. australis was significantly lower when grown on urea compared to nitrate and ammonium (Howard et al., 2007). Pseudo-nitzschia pseudodelicatissima (identity not certain) produced DA throughout the exponential phase, but the production was substantially higher in the late stationary phase (Adams et al., 2000).

The experiment with copepods in the present study was terminated when the cultures were still in the exponential growth phase. Thus, higher DA cell quotas than recorded in the exponential phase might have been observed in the stationary phase. However, with $C$. finmarchicus the toxicity of $P$. seriata decreased after day 5, suggesting that the potential chemical signal may be related to the actively grazing copepods. This is supported by the finding that the abundance of $P$. seriata decreased to very low levels during the experiment, meaning that $C$. finmarchicus practically stopped grazing before the end of the experiment. Selander et al. (2006) found that cues released by the grazing $A$. tonsa increased the PST content in the dinoflagellate $A$. minutum significantly more than cues released from the starving $A$. tonsa. Induction of colony formation in Scenedesmus acutus was also stronger when exposed to Daphnia exudates from feeding compared to starved grazers (Lampert et al., 1994). Similarly, Lürling (1998) observed that only exudates from Daphnia grazing on digestible food induced colony formation in $S$. acutus. Cues related to active feeding may thus be the most reliable indication of the risk of herbivory for phytoplankton (Van Donk et al., 2011), explaining why cues from actively grazing consumers may produce a stronger induction. 
The proportion of $P$. seriata cells in chains in direct contact with the copepods in flask A was relatively stable during the experiment. On days 5 and 8 with $C$. finmarchicus and on day 8 with $C$. hyperboreus, the proportion of the chains was lower compared to the control. This is likely due to a higher ingestion rate of chains, which may be easier for the copepods to detect due to their larger size compared to the single cells. On the contrary, in the B flasks without physical contact with the copepods, as well as in the control flasks, the proportion of chains increased during the experiment. Bergkvist et al. (2012) showed that the diatom Skeletonema marinoi reduced chain length in the presence of three copepod species; the response in $S$. marinoi was also induced without physical contact with A. tonsa. Grazing was significantly reduced on shorter chains compared to longer chains. The authors suggested that the suppression of chain formation in S. marinoi was a defense mechanism against copepod grazing (Bergkvist et al., 2012). In the present study, no effects of potential waterborne cues from the copepods on chain formation of $P$. seriata were observed. Indeed, in all the B flasks with cues from the copepods the proportion of cells in chains increased similar to the controls. In flask A, with direct physical contact with the copepods, possible cues may have suppressed chain formation in $P$. seriata but since the copepods were also grazing the cells, we cannot distinguish between the effects of these two factors. This is particularly relevant for $C$. finmarchicus, which almost exhausted the $P$. seriata cells by day 5 . The increased proportion of cells in chains compared to single cells during the experiment in the controls shows convincingly the tendency of $P$. seriata to form chains during exponential growth.

Our results suggest that potential chemical cues from $P$. seriata, produced by mechanical damage, do not induce the defense mechanisms addressed in the present study (increase in DA production, chain formation). Similarly, Lampert et al. (1994) and Lürling (1998) did not observe induction of colony formation in S. acutus when the alga was treated only with the cell homogenate of S. acutus instead of Daphnia exudates. Nor did we find any effects of possible cues from damaged cells on chain formation of $P$. seriata. However, we cannot exclude the possibility that any chemical cues released from damaged cells could interact with chemicals from the grazer and thus induce a stronger signal of the risk of being grazed upon, than if the chemical is released only by the grazer.

The highest DA cell quota of $P$. seriata observed in this study (13.1 pg DAcell ${ }^{-1}$ ) is in the range of the highest DA cell quotas recorded for $P$. seriata, (33.6 pg DA cell ${ }^{-1}$; during the stationary phase) (Lundholm et al., 1994). Prior to exposing $P$. seriata (P5G3) to the copepods in this study, the mean DA cell quota of $P$. seriata was below the limit of detection. The previous year, the average level was 0.55 pg DA cell $^{-1}$ (Tammilehto et al., 2012) and a substantially higher DA cell quota (47 pg DA cell ${ }^{-1}$, single measurement) for the strain was measured just 2 months before that. This illustrates the decrease in DA production over time in strains kept in culture for longer periods, even years (e.g. Bates et al., 1999). However, our study shows that the P. seriata strain (P5G3) used had not completely lost its ability to produce DA, because it then regained it when induced by the copepods. The decrease in DA production in unialgal laboratory cultures may thus illustrate the relaxation of an inducible defense.

Dissolved DA detected in flask A with C. hyperboreus is in the range of that previously reported in the culture medium of $P$. seriata, but the per cell production of dissolved DA was on average 23-250 times higher (Fehling et al., 2004; Hansen et al., 2011). Maldonado et al. (2002) found that P. multiseries and P. australis produced DA during the exponential growth phase in iron-deficient or toxic copper concentrations. Almost all (95\%) of the DA produced was released into the medium and the authors concluded this to be a stress reaction against unfavorable micronutrient levels (Maldonado et al., 2002). In the present study, $60 \%$ of the total
DA produced (cellular and dissolved) by $P$. seriata in physical contact with $C$. hyperboreus was released into the medium. This may have been an active stress response to the presence of a grazer, an involuntary leakage of DA due to the high intracellular DA concentration or a consequence of "sloppy" feeding by the copepods (Møller et al., 2003), leading to release of DA into the medium from the damaged cells.

In the present study, we did not see DA to deter grazing on $P$. seriata by the copepods. However, if DA production in P. seriata is induced by chemical cues released by calanoid copepods, it may, because of its toxicity, be assumed to be a defense mechanism against grazing. In this case, the risk of being grazed should be lower in the 'induced' cells in comparison to 'non-induced' cells. As previously mentioned, Selander et al. (2006) showed that the induced dinoflagellate $A$. minutum contained a higher PST cell quota than non-induced cells and that there was less grazing by the copepod A. tonsa on induced A. minutum compared to non-induced cells. Copepods may indeed stop grazing on the prey because it is toxic or otherwise unpalatable (behavioral selection) (Teegarden, 1999). In addition, grazing by copepods may be prevented by physiological incapacitation caused by toxic food (Huntley et al., 1986; Ives, 1987). Indications of $C$. finmarchicus and C. hyperboreus to stop grazing on toxic $P$. seriata after $6 \mathrm{~h}$ due to possible physiological incapacitation were found by Tammilehto et al. (2012). Bargu et al. (2003) found a similar effect when studying krill. Such a temporal grazing effect was not observed in the present study, probably because of the longer sampling intervals (2-3 days) compared to the $3 \mathrm{~h}$ interval used by Tammilehto et al. (2012). If DA deters grazing by copepods due to physiological incapacitation, the copepods are expected to reduce further grazing until the DA levels in the grazer are below a certain threshold level. Induction of higher production of DA in P. seriata due to the presence of grazers is therefore expected to result in a faster reduction of grazing. With regard to grazing, this would give toxic $P$. seriata an advantage at least in bloom conditions, because grazing on $P$. seriata would be impaired. Proving that the copepods are physiologically incapacitated by DA requires further studies. The hypothesis that DA causes physiological incapacitation in copepods does not conflict with findings showing that copepods do not select against toxic Pseudo-nitzschia species, even when nontoxic alternative food is offered (Maneiro et al., 2005; Olson et al., 2006; Leandro et al., 2010). The reason is that the negative effects of DA on grazers are expected to occur only if DA intake by the grazers is high enough, which may not have been the case in the studies by Maneiro et al. (2005), Olson et al. (2006) and Leandro et al. (2010), or that the effects of possible physiological incapacitation by DA are left unnoticed. DA may nevertheless have adverse effects on the fecundity of the grazers, which may lead to subsequent reduced grazing pressure. However, only two studies have addressed this question and found that feeding on toxic $P$. multiseries did not affect egg production or egg hatching success of the copepods A. tonsa (Lincoln et al., 2001) or A. clausi (Maneiro et al., 2005). Most copepod grazing experiments on toxic phytoplankton species, however, have not lasted more than $24 \mathrm{~h}$, which may be too short a time to detect the potential adverse effects of phycotoxins on grazers (Turner, 2014).

Assuming that the production of DA as a secondary metabolite is costly, it is more likely to be maintained by natural selection if it has several functions (Wink, 2003). In the present study, no costs of producing DA were observed, as there were no differences in growth rates between the highly toxic and the less toxic cells. However, there may be indirect costs that could not be detected in the batch cultures, as suggested by Bergkvist et al. (2008) and Selander et al. (2012) for the PST-producers A. minutum and A. tamarense, respectively. In the field, DA production is likely to be controlled by several interacting factors, which makes it difficult to predict the formation of a toxic bloom. This was emphasized by Marchetti et al. (2004), 
who in their field study concluded that environmental factors other than those studied so far (mainly related to nutrient stress) need to be examined to understand DA production in Pseudo-nitzschia species. Trainer et al. (2009) supported this view by stating that, under natural conditions, macronutrients cannot be used as reliable predictors of toxicity of a Pseudo-nitzschia bloom. Our study shows that zooplankton grazing could be one of the factors controlling the toxicity of a Pseudo-nitzschia bloom in the field. To our knowledge, this is the first study to address induction of DA production in Pseudo-nitzschia species by zooplankton. Given that other studies have shown toxin production in other algal groups can be induced by chemical cues from zooplankton (Jang et al., 2003; Selander et al., 2006, 2012), this possibility should be investigated more rigorously with other Pseudo-nitzschia species and zooplankton.

\section{Acknowledgements}

We thank the Arctic station in Qeqertarsuaq, Greenland, and the crew of the RV 'Porsild' for a great working atmosphere. We thank Hans Hansen, Olwen Grace, Laila Espersen, Jarkko Hujanen, Malene Møhl, and Rasmus Dyrmose Nørregaard for supporting the experiments in various ways, and Wolfgang Drebing for sample extraction and toxin measurements. Comments from two anonymous reviewers improved our paper. Funding was provided by Faculty of Science, University of Copenhagen (a FREJA stipend), the Carlsberg Foundation (projects 36370 and 2012-01-0556) and the Greenland Climate Research Centre (project 6505). Toxin measurements were supported by the Helmholtz Association of German Research Centers through the research programme Polar regions And Coasts in a changing Earth System (PACES) of the Alfred Wegener Institute.

\section{References}

Adams, N.G., Lesoing, M., Trainer, V.L., 2000. Environmental conditions associated with domoic acid in razor clams on the Washington coast. J. Shellfish Res. 19, 1007-1015

Bargu, S., Marinovic, B., Mansergh, S., Silver, M., 2003. Feeding responses of krill to the toxin-producing diatom Pseudo-nitzschia. J. Exp. Mar. Biol. Ecol. 284, 87-104, http://dx.doi.org/10.1016/S0022-0981(02)00494-X.

Bates, S.S., 1998. Ecophysiology and metabolism of ASP toxin production. In: Anderson, D.M., Cembella, A.D., Hallegraeff, G.M. (Eds.), Physiological Ecology of Harmful Algal Blooms, NATO ASI Series Series G Ecological Sciences. SpringerVerlag, Berlin/Heidelberg, pp. 405-426

Bates, S.S., Bird, C.J., de Freitas, A.S.W., Foxall, R., Gilgan, M., Hanic, L.A., Johnson, G.R., McCullough, A.W., Odense, P., Pocklington, R., Quilliam, M.A., Sim, P.G., Smith, J.C., Subba Rao, D.V., Todd, E.C.D., Walter, J.A., Wright, J.L.C., 1989. Pennate diatom Nitzschia pungens as the primary source of domoic acid, a toxin in shellfish from eastern Prince Edward Island, Canada. Can. J. Fish. Aquat. Sci. 46, 1203-1215, http://dx.doi.org/10.1139/f89-156.

Bates, S.S., Hiltz, M.F., Léger, C., 1999. Domoic acid toxicity of large new cells of Pseudo-nitzschia multiseries resulting from sexual reproduction. In: Martin, J.L., Haya, K. (Eds.), Proceedings of the Sixth Canadian Workshop on Harmful Marine Algae. Can. Tech. Rep. Fish. Aquat. Sci. 2261, 21-26.

Bates, S.S., Worms, J., Smith, J.C., 1993. Effects of ammonium and nitrate on growth and domoic acid production by Nitzschia pungens in batch culture. Can. J. Fish. Aquat. Sci. 50, 1248-1254, http://dx.doi.org/10.1139/f93-141.

Bergkvist, J., Selander, E., Pavia, H., 2008. Induction of toxin production in dinoflagellates: the grazer makes a difference. Oecologia 156, 147-154, http://dx.doi.org/10.1007/s00442-008-0981-6.

Bergkvist, J., Thor, P., Jakobsen, H.H., Wängberg, S.-Å., Selander, E., 2012. Grazerinduced chain length plasticity reduces grazing risk in a marine diatom. Limnol. Oceanogr. 57, 318-324, http://dx.doi.org/10.4319/lo.2012.57.1.0318.

Fehling, J., Davidson, K., Bolch, C.J., Bates, S.S., 2004. Growth and domoic acid production by Pseudo-nitzschia seriata (Bacillariophyceae) under phosphate and silicate limitation. J. Phycol. 40, 674-683, http://dx.doi.org/10.1111/j. 1529-8817.2004.03213.x.

Fritz, L., Quilliam, M.A., Wright, J.L.C., Beale, A.M., Work, T.M., 1992. An outbreak of domoic acid poisoning attributed to the pennate diatom Pseudonitzschia australis. J. Phycol. 28, 439-442, http://dx.doi.org/10.1111/j. 0022-3646.1992.00439.x.

Frost, B.W., 1972. Effects of size and concentration of food particles on the feeding behavior of the marine planktonic copepod Calanus pacificus. Limnol. Oceanogr. $17,805-815$.
Garrison, D.L., Conrad, S.M., Eilers, P.P., Waldron, E.M., 1992. Confirmation of domoic acid production by Pseudonitzschia australis (Bacillariophyceae) cultures. J. Phycol. 28, 604-607, http://dx.doi.org/10.1111/j.0022-3646.1992.00604.x.

Guillard, R.R.L., Hargraves, P.E., 1993. Stichochrysis immobilis is a diatom, not a chrysophyte. Phycologia 32, 234-236.

Hansen, H.P., Koroleff, F., 1999. Determination of nutrients. In: Grasshoff, K., Kremling, K., Ehrhardt, M. (Eds.), Methods of Seawater Analysis. Wiley-VCH Verlag GmbH, pp. 159-228.

Hansen, L.R., Soylu, S.í., Kotaki, Y., Moestrup, Ø., Lundholm, N., 2011. Toxin production and temperature-induced morphological variation of the diatom Pseudo-nitzschia seriata from the Arctic. Harmful Algae 10, 689-696, http://dx.doi.org/10.1016/j.hal.2011.05.004.

Hansen, M.O., Nielsen, T.G., Stedmon, C.A., Munk, P., 2012. Oceanographic regime shift during 1997 in Disko Bay, Western Greenland. Limnol. Oceanogr. 57, 634-644, http://dx.doi.org/10.4319/lo.2012.57.2.0634.

Harris, R.P., Wiebe, P.H., Lenz, J., Skjoldal, H.R., Huntley, M. (Eds.), 2005. Zooplankton Methodology Manual. , repr. ed. Elsevier Academic Press, China.

Hessen, D.O., Van Donk, E., 1993. Morphological changes in Scenedesmus induced by substances released from Daphnia. Arch. Hydrobiol. 127, 129-140.

Howard, M.D.A., Cochlan, W.P., Ladizinsky, N., Kudela, R.M., 2007. Nitrogenous preference of toxigenic Pseudo-nitzschia australis (Bacillariophyceae) from field and laboratory experiments. Harmful Algae 6, 206-217, http://dx.doi.org/10.1016/j.hal.2006.06.003.

Huntley, M., Sykes, P., Rohan, S., Marin, V., 1986. Chemically-mediated rejection of dinoflagellate prey by the copepods Calanus pacificus and Paracalanus parvus: mechanism, occurrence and significance. Mar. Ecol. Prog. Ser. 28, 105-120.

Ives, J.D., 1987. Possible mechanisms underlying copepod grazing responses to levels of toxicity in red tide dinoflagellates. J. Exp. Mar. Biol. Ecol. 112, 131-144.

Jakobsen, H.H., Tang, K.W., 2002. Effects of protozoan grazing on colony formation in Phaeocystis globosa (Prymnesiophyceae) and the potential costs and benefits. Aquat. Microb. Ecol. 27, 261-273, http://dx.doi.org/10.3354/ame027261.

Jang, M.-H., Ha, K., Joo, G.-J., Takamura, N., 2003. Toxin production of cyanobacteria is increased by exposure to zooplankton. Freshw. Biol. 48, 1540-1550, http://dx.doi.org/10.1046/j.1365-2427.2003.01107.x.

Jespersen, A.M., Christoffersen, K., 1987. Measurements of chlorophyll-a from phytoplankton using ethanol as extraction solvent. Arch. Hydrobiol. 109, 445-454.

Jiang, X., Lonsdale, D.J., Gobler, C.J., 2010. Grazers and vitamins shape chain formation in a bloom-forming dinoflagellate, Cochlodinium polykrikoides. Oecologia 164 455-464, http://dx.doi.org/10.1007/s00442-010-1695-0.

Karban, R., Baldwin, I.T., 1997. Induced Responses to Herbivory. The University of Chicago Press, Chicago.

Lampert, W., Rothhaupt, K.O., von Elert, E., 1994. Chemical induction of colony formation in a green alga (Scenedesmus acutus) by grazers (Daphnia). Limnol. Oceanogr. 39, 1543-1550.

Leandro, L.F., Teegarden, G.J., Roth, P.B., Wang, Z., Doucette, G.J., 2010. The copepod Calanus finmarchicus: a potential vector for trophic transfer of the marine algal biotoxin, domoic acid. J. Exp. Mar. Biol. Ecol. 382, 88-95, http://dx.doi.org/10.1016/j.jembe.2009.11.002.

Lefebvre, K.A., Frame, E.R., Kendrick, P.S., 2012. Domoic acid and fish behavior: a review. Harmful Algae 13, 126-130, http://dx.doi.org/10.1016/j.hal.2011.09.011.

Lelong, A., Hégaret, H., Soudant, P., Bates, S.S., 2012. Pseudo-nitzschia (Bacillariophyceae) species, domoic acid and amnesic shellfish poisoning: revisiting previous paradigms. Phycologia 51, 168-216, http://dx.doi.org/10.2216/11-37.

Lincoln, J.A., Turner, J.T., Bates, S.S., Léger, C., Gauthier, D.A., 2001. Feeding, egg production, and egg hatching success of the copepods Acartia tonsa and Temora longicornis on diets of the toxic diatom Pseudo-nitzschia multiseries and the non-toxic diatom Pseudo-nitzschia pungens. Hydrobiologia 453, 107-120, http://dx.doi.org/10.1023/A:1013163816771.

Long, J.D., Smalley, G.W., Barsby, T., Anderson, J.T., Hay, M.E., 2007. Chemical cues induce consumer-specific defenses in a bloom-forming marine phytoplankton. Proc. Natl. Acad. Sci. U.S.A. 104, 10512-10517, http://dx.doi.org/10.1073/pnas.0611600104.

Lundgren, V., Granéli, E., 2010. Grazer-induced defense in Phaeocystis globosa (Prymnesiophyceae): Influence of different nutrient conditions. Limnol. Oceanogr. 55, 1965-1976, http://dx.doi.org/10.4319/lo.2010.55.5.1965.

Lundholm, N., Skov, J., Pocklington, R., Moestrup, Ø., 1994. Domoic acid, the toxic amino acid responsible for amnesic shellfish poisoning, now in Pseudonitzschia seriata (Bacillariophyceae) in Europe. Phycologia 33, 475-478 http://dx.doi.org/10.2216/i0031-8884-33-6-475.1.

Lundholm, N., Hansen, P.J., Kotaki, Y., 2004. Effect of $\mathrm{pH}$ on growth and domoic acid production by potentially toxic diatoms of the genera Pseudo-nitzschia and Nitzschia. Mar. Ecol. Prog. Ser. 273, 1-15, http://dx.doi.org/10.3354/meps273001.

Lundholm, N., Hansen, P.J., Kotaki, Y., 2005. Lack of allelopathic effects of the domoic acid-producing marine diatom Pseudo-nitzschia multiseries. Mar. Ecol. Prog. Ser. 288, 21-33, http://dx.doi.org/10.3354/meps288021.

Lürling, M., 1998. Effect of grazing-associated infochemicals on growth and morphological development in Scenedesmus acutus (Chlorophyceae). J. Phycol. 34, 578-586, http://dx.doi.org/10.1046/j.1529-8817.1998.340578.x.

Lürling, M., 2001. Grazing-associated infochemicals induce colony formation in the green alga Scenedesmus. Protist 152, 7-16, http://dx.doi.org/10. 1078/1434-4610-00038.

Madsen, S.D., Nielsen, T.G., Hansen, B.W., 2001. Annual population development and production by Calanus finmarchicus, C. glacialis and C. hyperboreus in Disko Bay, western Greenland. Mar. Biol. 139, 75-93. 
Maldonado, M.T., Hughes, M.P., Rue, E.L., Wells, M.L., 2002. The effect of Fe and $\mathrm{Cu}$ on growth and domoic acid production by Pseudo-nitzschia multiseries and Pseudo-nitzschia australis. Limnol. Oceanogr. 47, 515-526.

Maneiro, I., Iglesias, P., Guisande, C., Riveiro, I., Barreiro, A., Zervoudaki, S., Granéli, E., 2005. Fate of domoic acid ingested by the copepod Acartia clausi. Mar. Biol. 148, 123-130, http://dx.doi.org/10.1007/s00227-005-0054-x.

Marchetti, A., Trainer, V.L., Harrison, P.J., 2004. Environmental conditions and phytoplankton dynamics associated with Pseudo-nitzschia abundance and domoic acid in the Juan de Fuca eddy. Mar. Ecol. Prog. Ser. 281, 1-12, http://dx.doi.org/10.3354/meps281001.

McHuron, E.A., Greig, D.J., Colegrove, K.M., Fleetwood, M., Spraker, T.R., Gulland, F.M.D., Harvey, J.T., Lefebvre, K.A., Frame, E.R., 2013. Domoic acid exposure and associated clinical signs and histopathology in Pacific harbor seals (Phoca vitulina richardii). Harmful Algae 23, 28-33, http://dx.doi.org/10.1016/j.hal.2012.12.008.

Møller, E.F., Thor, P., Nielsen, T.G., 2003. Production of DOC by Calanus finmarchicus, C. glacialis and C. hyperboreus through sloppy feeding and leakage from fecal pellets. Mar. Ecol. Prog. Ser. 262, 185-191, http://dx.doi.org/10.3354/meps262185.

Olson, M.B., Lessard, E.J., Wong, C.H.J., Bernhardt, M.J., 2006. Copepod feeding selectivity on microplankton, including the toxigenic diatoms Pseudo-nitzschia spp., in the coastal Pacific Northwest. Mar. Ecol. Prog. Ser. 326, 207-220, http://dx.doi.org/10.3354/meps326207.

Scholin, C.A., Gulland, F., Doucette, G.J., Benson, S., Busman, M., Chavez, F.P., Cordaro, J., DeLong, R., De Vogelaere, A., Harvey, J., Haulena, M., Lefebvre, K., Lipscomb, T., Loscutoff, S., Lowenstine, L.J., Marin III, R., Miller, P.E., McLellan, W.A., Moeller, P.D.R., Powell, C.L., Rowles, T., Silvagni, P., Silver, M., Spraker, T., Trainer, V., Van Dolah, F.M., 2000. Mortality of sea lions along the central California coast linked to a toxic diatom bloom. Nature 403, 80-84, http://dx.doi.org/10.1038/47481.

Selander, E., Thor, P., Toth, G., Pavia, H., 2006. Copepods induce paralytic shellfish toxin production in marine dinoflagellates. Proc. R. Soc. B-Biol. Sci. 273, 1673-1680, http://dx.doi.org/10.1098/rspb.2006.3502.

Selander, E., Cervin, G., Pavia, H., 2008. Effects of nitrate and phosphate on grazerinduced toxin production in Alexandrium minutum. Limnol. Oceanogr. 53, 523-530, http://dx.doi.org/10.4319/lo.2008.53.2.0523.

Selander, E., Jakobsen, H.H., Lombard, F., Kiørboe, T., 2011. Grazer cues induce stealth behavior in marine dinoflagellates. Proc. Natl. Acad. Sci. 108, 4030-4034, http://dx.doi.org/10.1073/pnas.1011870108.

Selander, E., Fagerberg, T., Wohlrab, S., Pavia, H., 2012. Fight and flight in dinoflagellates? Kinetics of simultaneous grazer-induced responses in Alexandrium tamarense. Limnol. Oceanogr. 57, 58-64, http://dx.doi.org/10.4319/lo. 2012.57.1.0058.

Shaw, B.A., Andersen, R.J., Harrison, P.J., 1997. Feeding deterrent and toxicity effects of apo-fucoxanthinoids and phycotoxins on a marine copepod (Tigriopus californicus). Mar. Biol. 128, 273-280.
Sun, J., Hutchins, D.A., Feng, Y, Seubert, E.L., Caron, D.A., Fu, F.-X., 2011. Effects of changing $\mathrm{pCO}_{2}$ and phosphate availability on domoic acid production and physiology of the marine harmful bloom diatom Pseudo-nitzschia multiseries. Limnol. Oceanogr. 56, 829-840, http://dx.doi.org/10.4319/lo.2011.56.3. 0829.

Tammilehto, A., Nielsen, T.G., Krock, B., Møller, E.F., Lundholm, N., 2012. Calanus spp. -Vectors for the biotoxin, domoic acid, in the Arctic marine ecosystem? Harmful Algae 20, 165-174, http://dx.doi.org/10.1016/j.hal.2012.10.004.

Tang, K.W., 2003. Grazing and colony size development in Phaeocystis globosa (Prymnesiophyceae): the role of a chemical signal. J. Plankton Res. 25, 831-842, http://dx.doi.org/10.1093/plankt/25.7.831.

Teegarden, G.J., 1999. Copepod grazing selection and particle discrimination on the basis of PSP toxin content. Mar. Ecol. Prog. Ser. 181, 163-176 http://dx.doi.org/10.3354/meps181163.

Tester, P.A., Pan, Y., Doucette, G.J., 2001. Accumulation of domoic acid activity in copepods. In: Hallegraeff, G.M., Blackburn, S.I., Bolch, C.J., Lewis, R.J. (Eds.), Harmful Algal Blooms 2000. Intergovernmental Oceanographic Commission of UNESCO, France, pp. 418-420.

Thessen, A.E., Bowers, H.A., Stoecker, D.K., 2009. Intra- and interspecies differences in growth and toxicity of Pseudo-nitzschia while using different nitrogen sources. Harmful Algae 8, 792-810, http://dx.doi.org/10.1016/j.hal.2009.01.003.

Trainer, V.L., Hickey, B.M., Lessard, E.J., Cochlan, W.P., Trick, C.G., Wells, M.L., MacFadyen, A., Moore, S.K., 2009. Variability of Pseudo-nitzschia and domoic acid in the Juan de Fuca eddy region and its adjacent shelves. Limnol. Oceanogr. 54 289-308, http://dx.doi.org/10.4319/lo.2009.54.1.0289.

Trainer, V.L., Bates, S.S., Lundholm, N., Thessen, A.E., Cochlan, W.P., Adams, N.G., Trick, C.G., 2012. Pseudo-nitzschia physiological ecology, phylogeny, toxicity, monitoring and impacts on ecosystem health. Harmful Algae 14, 271-300, http://dx.doi.org/10.1016/j.hal.2011.10.025.

Trimborn, S., Lundholm, N., Thoms, S., Richter, K.-U., Krock, B., Hansen, P.J., Rost, B. 2008. Inorganic carbon acquisition in potentially toxic and non-toxic diatoms: the effect of $\mathrm{pH}$-induced changes in seawater carbonate chemistry. Physiol. Plant 133, 92-105, http://dx.doi.org/10.1111/j.1399-3054.2007.01038.x.

Turner, J.T., 2014. Planktonic marine copepods and harmful algae. Harmful Algae 32 81-93, http://dx.doi.org/10.1016/j.hal.2013.12.001.

Van Donk, E., Ianora, A., Vos, M., 2011. Induced defences in marine and freshwater phytoplankton: a review. Hydrobiologia 668, 3-19, http://dx.doi.org/10.1007/s10750-010-0395-4.

Wink, M., 2003. Evolution of secondary metabolites from an ecological and molecular phylogenetic perspective. Phytochemistry 64, 3-19, http://dx.doi.org/10.1016/S0031-9422(03)00300-5. 